\title{
Effects of the Addition of Fe, Co on the Azo Dye Degradation Ability of Mn-Al Mechanically Alloyed Powders
}

\author{
Wael Ben Mbarek ${ }^{1}$, Joan Saurina ${ }^{1}$, Lluisa Escoda ${ }^{1}$, Eloi Pineda ${ }^{2} \oplus$, Mohamed Khitouni ${ }^{3}$ and \\ Joan-Josep Suñol 1,*(D) \\ 1 Department of Physics, Campus Montilivi, s/n University of Girona, 17003 Girona, Spain; \\ u1930157@correu.campus.udg.edu (W.B.M.); joan.saurina@udg.edu (J.S.); lluisa.escoda@udg.edu (L.E.) \\ 2 Department of Physics and nuclear Engineering, Campus Diagonal Besòs, Polytechnic University of \\ Catalonia, 08019 Barcelona, Spain; eloi.pineda@upc.edu \\ 3 Inorganic Chemistry Laboratory, UR-11-ES-73, University of Sfax, Sfax BP 1171, Tunisia; \\ mohamed.khitouni@fss.rnu.tn \\ * Correspondence: joanjosep.sunyol@udg.edu; Tel.: +34-972-419-757
}

Received: 15 October 2020; Accepted: 22 November 2020; Published: 25 November 2020

\begin{abstract}
Azo compounds are used in the textile and leather industry. A significant step during the azo dyes treatment of water is the degradation by breaking the $\mathrm{N}=\mathrm{N}$ bonds. This break produces the decolorization of water. In this research work, $10 \%$ atomic of Fe or Co was added to produce ternary Mn-Al-rich, nanostructured, mechanically alloyed powders in order to improve the decolorization of Reactive Black 5 solutions and to check Fe and Co addition's influence. The microstructure was followed by $X$-ray diffraction, the morphology and composition by electronic microscopy and energy-dispersive $\mathrm{X}$-ray spectroscopy (EDS) microanalysis. The dye degradation was monitored with ultraviolet/visible absorption spectrophotometry. After degradation, the remaining organic compound was checked by high-performance liquid chromatography (HPLC) and the functional groups of the powdered alloys by infrared spectroscopy. Fe addition to $\mathrm{Mn}$-Al displayed faster kinetics and a higher efficiency than the Co addition. The Mn-Al-Fe solution $(0.25 \mathrm{~g} / 100 \mathrm{~mL})$ was fully decolorized in $5 \mathrm{~min}$. On the other side, $\mathrm{Mn}$-Al-Co powders were able to successfully decolorize the dyed solution in $10 \mathrm{~min}$ under the same conditions. Thus, nanocrystalline Fe-doped $\mathrm{Mn}-\mathrm{Al}$ alloys are good candidates for use in the decolorization process, in comparison with Co-doped and other intermetallic particles.
\end{abstract}

Keywords: mechanical alloying; reactive black 5; decolorization; UV-visible spectrophotometry; LC-MS analysis

\section{Introduction}

The industrial water effluent is one important source of pollution in the environment [1]. The dye effluents from textile industries are significant sources of pollution (high toxicity, low biodegradation rate) [2]. Various processes and materials have been proposed in the scientific literature for wastewater treatment. Some examples are: adsorption onto granular activated carbon [3], hollow fiber ultrafiltration [4], coagulation-flocculation with Detarium microcarpum [5], biological oxidation [6], or some photocatalyst methods and materials [7,8] including a magnetic photocatalyst [9]. One of the methods is reduction with zero valent metals or alloys [10]. They have been applied for removing azo dyes [7] as well as metals and chlorinated organics [11-14].

The metallic particles (MPs) have been applied as elements or as alloys to facilitate the reduction process. The microstructure of the particles can be amorphous or crystalline. Usually, the best 
results are found in amorphous because the corrosion resistance and chemical interaction are usually improved if the comparison is performed with crystalline alloys with the same composition [15]. Thus, as microstructure affects the functional behavior, in this work, we analyze some nanocrystalline Mn-rich alloys. Nanocrystalline materials have a crystalline structure, and between 10 and 50\% of atoms are in the grain boundaries between crystalline grains. In the scientific literature, there are interesting works about the degradation induced by MPs in dyes (by chemical reaction, breaking bonds). One of the main topics is the analysis of the degradation reaction by taking into account the particle's surface activity (with the organic contaminants) of the metallic particles $[16,17]$. The reaction of degradation of the dye molecules is based on a redox process. On the surface of the metallic alloys, the metallic atoms lose electrons. These electrons are effective to cleave the active bonds (as the azo dye $-\mathrm{N}=\mathrm{N}$ - bonds) of organic molecules [18-22].

There are some methods that help to develop metallic particles: precipitation (magnetite, iron) [23,24], gas atomization (high-entropy alloys) [25] or mechanical alloying (Mn-Al-based alloys) $[19,22]$. In the mechanical alloying (or ball milling) process, particles yield severe plastic deformation, producing stress and strains. Thus, the mechanical deformation favors the development of metastable microstructures (amorphous, nanocrystalline) and, subsequently, the mechanical and functional properties are different from crystalline alloys with the same composition [26].

In this work, we analyze the azo dye degradation ability by improving the rate of the degradation reaction of ternary $\mathrm{Mn}-\mathrm{Al}-(\mathrm{Fe}, \mathrm{Co})$ nanocrystalline powders produced by mechanical alloying. A high degradation rate will favor the integration of this material as a preliminary step procedure for the full degradation of azo dye wastewaters.

In previous works, we reported the high efficiency of Manganese-Aluminum (Mn-Al) particles in the degradation of azo-dyes: reactive black 5 (RB5) [19] and orange II [21]. It should be remarked that $\mathrm{Mn}$ and $\mathrm{Al}$ (as biocompatible elements) are used in environmental and biomedical applications [27].

\section{Materials and Methods}

The $\mathrm{Mn}_{60} \mathrm{Al}_{30} \mathrm{Fe}_{10}$ and $\mathrm{Mn}_{60} \mathrm{Al}_{20} \mathrm{Co}_{10}$ (at.\%) alloys were produced from elemental high-purity (<99.9 at.\%) Mn, Al, Fe or Co by mechanical alloying (MA) under an Ar atmosphere for $15 \mathrm{~h}$ at $500 \mathrm{rpm}$. Cycles (10 min milling/5 min off) are applied to prevent the excessive heating, with the inversion of the rotation in each cycle (to prevent powders sticking to milling media).

The morphology, composition, surface area, and microstructure of the powders were explored with scanning electron microscopy (SEM) at $15 \mathrm{kV}$. Being integrated in the SEM equipment, microanalysis was performed by energy-dispersive X-ray spectroscopy (EDS, Vega@Tescan, Brno, Czech Republic). The reactivity is linked to the specific surface area of the $\mathrm{Mn}-\mathrm{Al}-(\mathrm{Fe}, \mathrm{Co})$ powders. This specific area is determined by the gas multilayer adsorption method in a BET device (Micromeritics ASAP 2010 M, Norcross, GA, USA) under nitrogen, after degassing the powder at $300^{\circ} \mathrm{C}$ for $24 \mathrm{~h}$. The microstructure was determined at room temperature by X-ray diffraction (XRD, Siemens/Bruker D500, Billerica, MA, USA) using $\mathrm{Cu}-\mathrm{K}_{\alpha}$ radiation.

In order to assess the colorant (RB5) degradation reaction, an aqueous solution (dye concentration: $40 \mathrm{mg} \mathrm{L}^{-1}$ ). The procedure was described and portrayed in previous works $[19,20]$. The produced supernatants were separated, and the color intensity was measured at the maximum absorption wavelength by ultraviolet-visible absorption spectrophotometry (UV-Vis, Shimadzu 2600, Kyoto, Japan), wavelength scan in the range between 200 and $800 \mathrm{~nm}$ ).

To check whether these materials can be used in the integrated treatment of wastewater, it is necessary to analyze the metallic powders after degradation as well as the remaining wastewater liquid (the procedure described in references 19 and 20). The powder collected after degradation was analyzed using Fourier transform infrared spectroscopy (FTIR) (Bruker, Billerica, MA, USA) and the concentrations of the metal ions checked by absorption spectrophotometer according to standard methods [19]. The organic compounds from the RB5 degradation were analyzed by high-performance liquid chromatography (HPLC) (Agilent, Santa Clara, CA, USA) coupled with 
tandem mass spectrometry (LC-MS/MS, Bruker, Billerica, MA, USA) in a Beckman Gold chromatograph fitted with a Proshell 120 Pheny Hexyl column at room temperature.

\section{Results}

First, we check powders morphology and composition. Figure $1 \mathrm{a}, \mathrm{b}$ displays the surface morphology of the MA Mn-Al-Fe powder. As exhibited in the figure, many corrugations appear on the surface of the nanostructured powders. The EDS microanalysis finding reported in Figure 1c does not reveal significant contamination by the production process (milling tools) and the MA powder is mainly composed (in the volume) of the precursors. The $C$ is due to the sputtering process used to prepare samples for SEM observation. Oxygen contamination is typical of powdered metals with a high surface/volume ratio due to contact with the air before and after the MA process in the Ar atmosphere. Furthermore, oxides were undetected in the powders. The atomic concentration of the elements (Mn, $\mathrm{Al}$ and $\mathrm{Fe}$ ) is 57:31:12, These values are similar to those of the nominal composition: 60:30:10. It should be remarked that EDS is considered as a semi-quantitative method. The size distribution of the powders (by neglecting big powders associated with conglomerates) is provided in Figure 1d (mean particle size is $\approx 10 \mu \mathrm{m}$, the accuracy of the size is $0.5 \mu \mathrm{m}$ and the standard deviation $3.6 \mu \mathrm{m}$ ). The micrographs of the Mn-Al-Co as-produced powder are illustrated in Figure 2a,b. As expected in ball-milled alloys, smooth surfaces, particle aggregation and corrugations were found. The EDS microanalysis (Figure 2c) proves that the Mn:Al:Co ratio was approximately equal to 55:34:11, similar to the 60:30:10 nominal composition. Likewise, the distribution of the particles size is shown in Figure 2d. For statistical comparison, the particle size distribution was also analyzed. The average particle size found to be slightly lower than those of Mn-Al-Fe particles, at $\approx 9 \mu \mathrm{m}$ (this slight difference can be influenced by the particle selection manual procedure for SEM analysis), and the standard deviation is $1.9 \mu \mathrm{m}$.

The decolorization was checked by analyzing the solutions described in the materials and methods section. Figure 3a presents the image of RB5 solutions before and after the addition of MA powders $\left(25^{\circ} \mathrm{C}\right)$. It is clear that the discoloration of the RB5 aqueous solution RB5 is very successful. The supernatants of the aqueous solution of RB5 treated with the two ternary powders Mn-Al-Fe and Mn-Al-Co were separated, respectively, at 0.5, 1, 2, 3, 4 and $5 \mathrm{~min}$ as well as 0, 1, 5, 10, 15 and $20 \mathrm{~min}$. Figure $3 b, c$ shows the evolution of absorbance of different aqueous supernatant portions which were measured by UV-Vis absorption spectrophotometry. For the ternary compound Mn-Al-Fe, the solution is fully discolored in $5 \mathrm{~min}$ (Figure 3b), whereas the solution treated with the Mn-Al-Co powder is fully discolored in $20 \mathrm{~min}$ (Figure 3c). The peak at $597 \mathrm{~nm}$ of the absorbance is associated to the azo dye concentration in the solution $[19,20,28]$. This peak in the visible region is associated to the "-N=N-" bonds and to the dye molecule concentration in the solution. Thus, the decrease in the intensity (as the reaction time in the solution increases) at $597 \mathrm{~nm}$ is an indicator of the degradation and RB5 chromophores' evolution. Likewise, the bands (at 230 and $310 \mathrm{~nm}$ ) in the ultraviolet region are assigned, respectively, to the benzene and naphthalene rings of the molecule dye $[19,20,29,30]$. These bands, at $\lambda_{\max }$, become weaker with degradation time. This effect is linked to: (a) the cleavage of the azo bands (also confirmed by the increase of $246 \mathrm{~nm}$ in the absorbance peak), (b) the formation of $\left(-\mathrm{NH}_{2}\right)$ groups, (c) the decomposition of $\mathrm{RB} 5$ in the solution. This result was also found by Zhang and coworkers [31], who confirmed the reductive degradation by amorphous Fe of azo acid orange II solution and Ben Mbarek et al. [19,20], who highlighted the rapid degradation of azo-dye with mechanically alloyed nanocrystalline $\mathrm{Mn}-\mathrm{Al}$ alloys, as well as the high-efficiency decolorization of azo dyes by Ca-Al particles. 

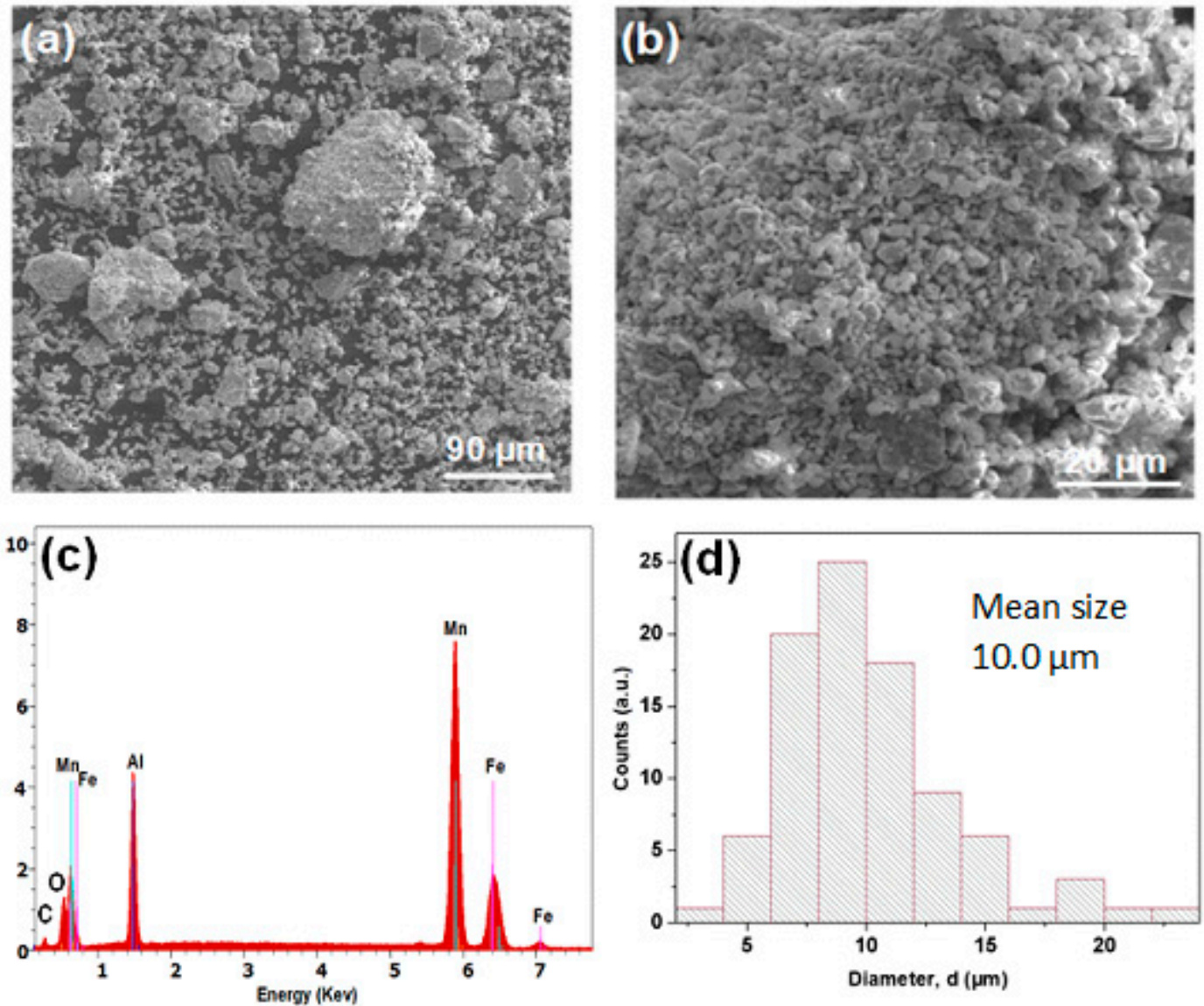

Figure 1. (a,b) Micrographs of the mechanical alloying (MA) Mn-Al-Fe. (c) Energy-dispersive X-ray spectroscopy (EDS) microanalysis and (d) distribution of particle sizes of the mechanically alloyed powder.

The mechanism of the redox reaction is viewed to be practically the same as for the case of the binary Mn-Al. However, the rates of RB5 bleaching reaction under the same dosage and temperature conditions using the Mn-Al-Fe and Mn-Al-Co powders appear to be different. The different potentials of the reduction in Fe and Co could account for these discrepancies, as well as the different solubilities of their hydroxides. It is known that the standard oxidation potential $\mathrm{Co} / \mathrm{Co}^{2+}$ is less negative than the oxidation potential of $\mathrm{H}^{+} / \mathrm{H}_{2}$, whereas the standard oxidation potential of $\mathrm{Fe} / \mathrm{Fe}^{2+}$ is more negative ( -0.29 and $-0.44 \mathrm{~V}$, respectively), which makes the transfer of electrons between $\mathrm{Co}$ and $\mathrm{H}^{+}$slower than that occurring between the $\mathrm{Fe}$ and $\mathrm{H}^{+}$[32]. For the improvement in the azo bond-breaking, $\mathrm{Co} / \mathrm{Fe}$ are active actors favoring the production of hydrogen from water [31,33-35].

Another factor to consider is the different adsorption capacity of both elements. The valence electrons (metal atoms) are shared by all atoms to form a cloud of electrons in a highly shared state. The valence electron configurations are $3 d^{6} 4 s^{2}(\mathrm{Fe})$ and $3 d^{7} 4 s^{2}(\mathrm{Co})$. Magnetic data showed that there was an average of 2.2 and 1.7 holes in the $\mathrm{d}$ band for Fe and Co, respectively [36]. The more holes in the bands, the more unpaired electrons there are. Therefore, the interaction between unpaired electrons and adsorbate molecules favors the formation of a localized adsorption bond. Thus, higher adsorption capacity is linked to the unpaired electrons. Simultaneously to the adsorption of the RB5 molecule, a reduction in the azo group might take place on the surface of the metallic powder. Thus, the selected value to follow the kinetics reaction was the maximum absorption wavelength. The compound $\mathrm{Mn}-\mathrm{Al}-\mathrm{Fe}$ exhibits the highest decolorization process reaction rate in the first five minutes, since it has the highest concentration of d-band holes per unit atom [36]. However, the compound $\mathrm{Mn}-\mathrm{Al}-\mathrm{Co}$ displays a lower adsorption rate (Figure 3d). 

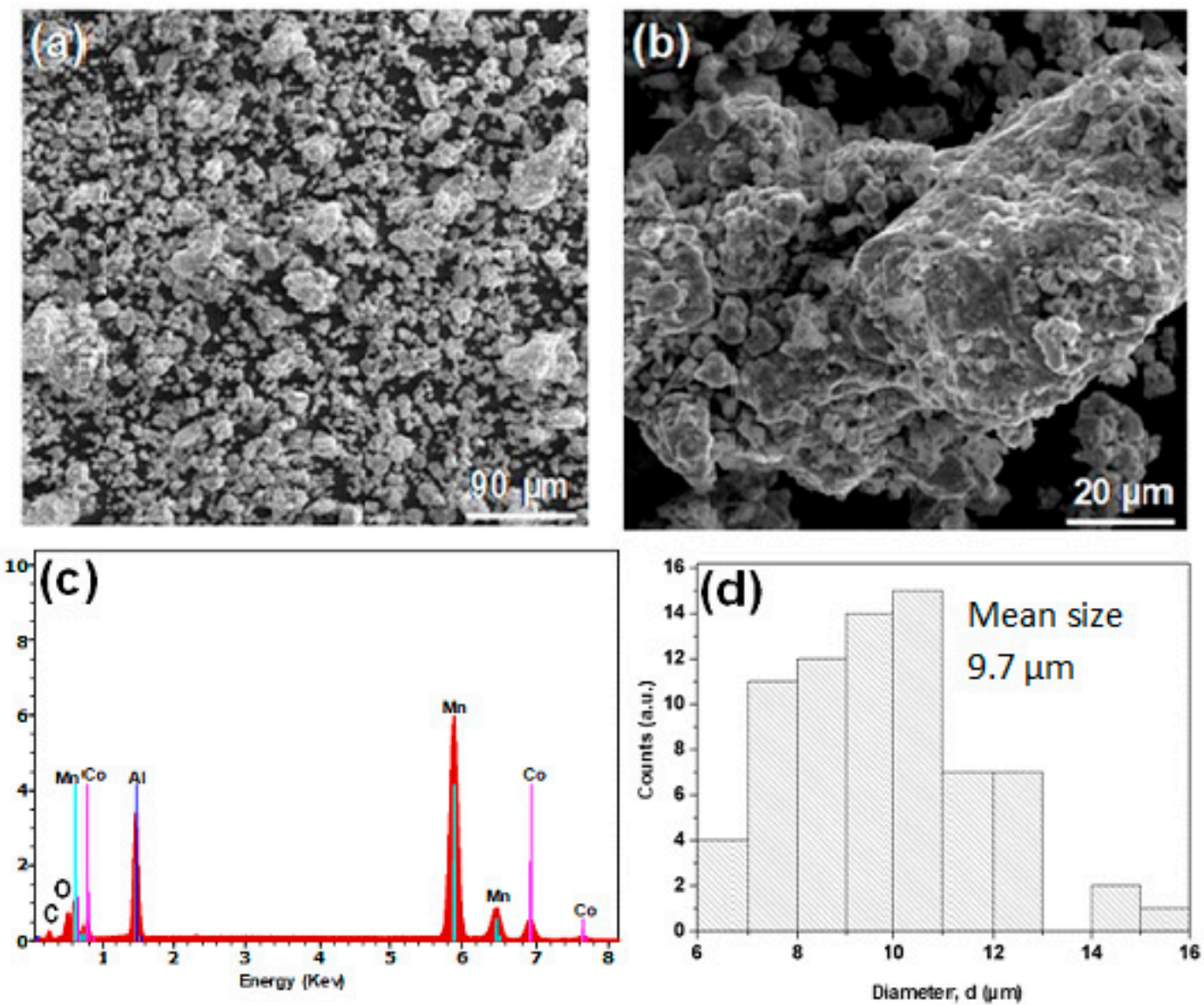

Figure 2. (a,b) Particle morphologies of the MA Mn-Al-Co powder. (c) EDS microanalysis and (d) distribution of particle sizes of the ball milled powder.

As shown in Figure 4, a straight line of $\ln \left(\mathrm{C} / \mathrm{C}_{\mathrm{o}}\right)$ versus reaction time was achieve, with coefficients of determination $\mathrm{R}^{2}(0.9322$ and 0.9813 , values $>0.9$ ). Therefore, the decolorization of $\mathrm{R} 5$ solution is consistent with first-order kinetics. The slope of the alloy with Fe addition is $0.9725 \mathrm{~s}^{-1}$, higher than $0.1717 \mathrm{~s}^{-1}$ (Mn-Al-Co). The Mn-Al-Co value is also higher than those of Mn-Al $\left(0.2154 \mathrm{~s}^{-1}\right)$. Thus, Co addition does not provoke a significant change in the decolorization efficiency, whereas Fe addition favors the process. 
(a)
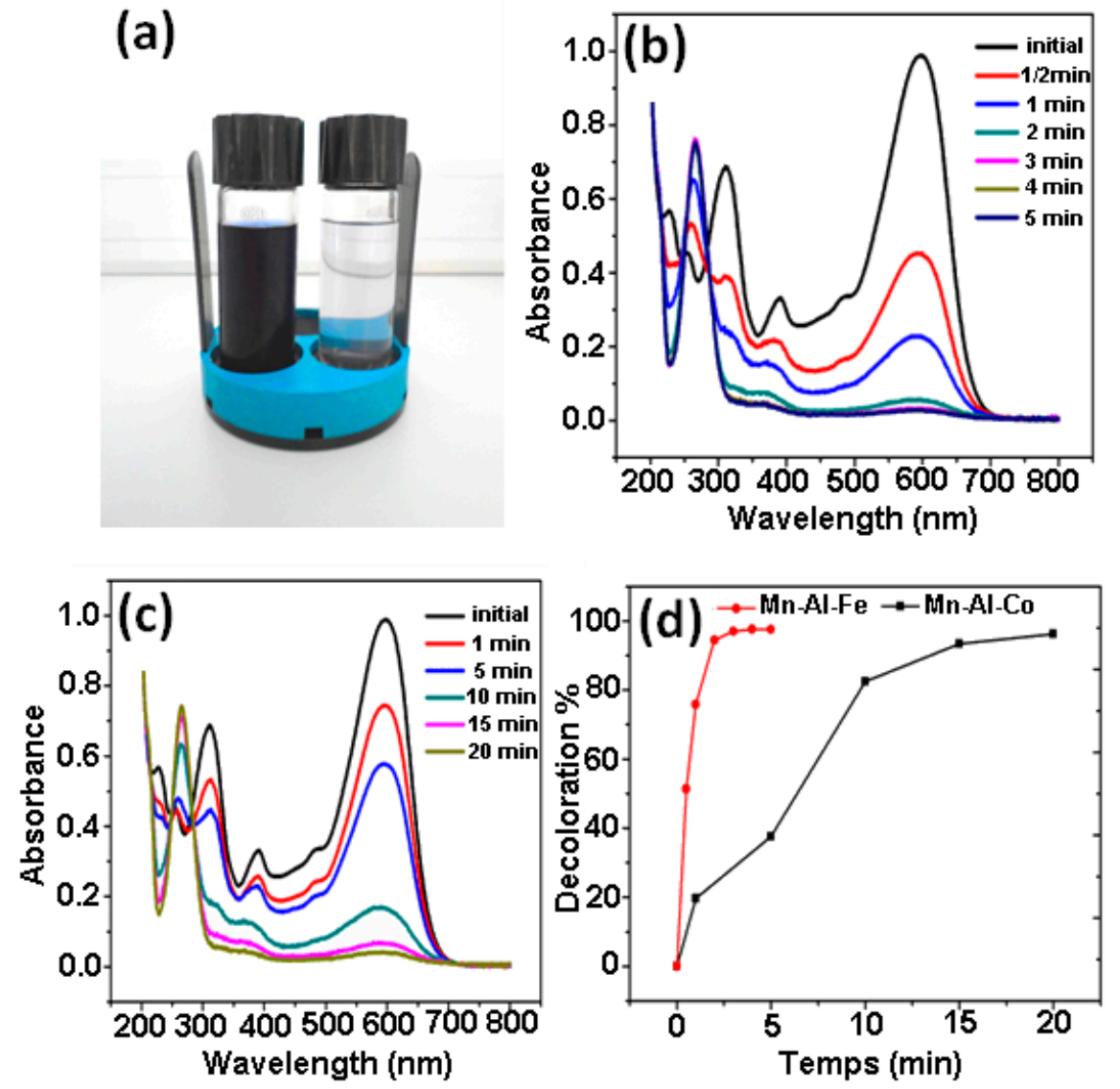

Figure 3. (a) Image of black 5 solutions processed by MA powder before and after degradation. (b) UV absorption spectra at different times for Mn-Al-Fe alloy. (c) UV absorption spectra at different times for Mn-Al-Co alloy. (d) The decolorization \% from UV absorption intensity at $597 \mathrm{~nm}$ versus reaction time for both alloys.

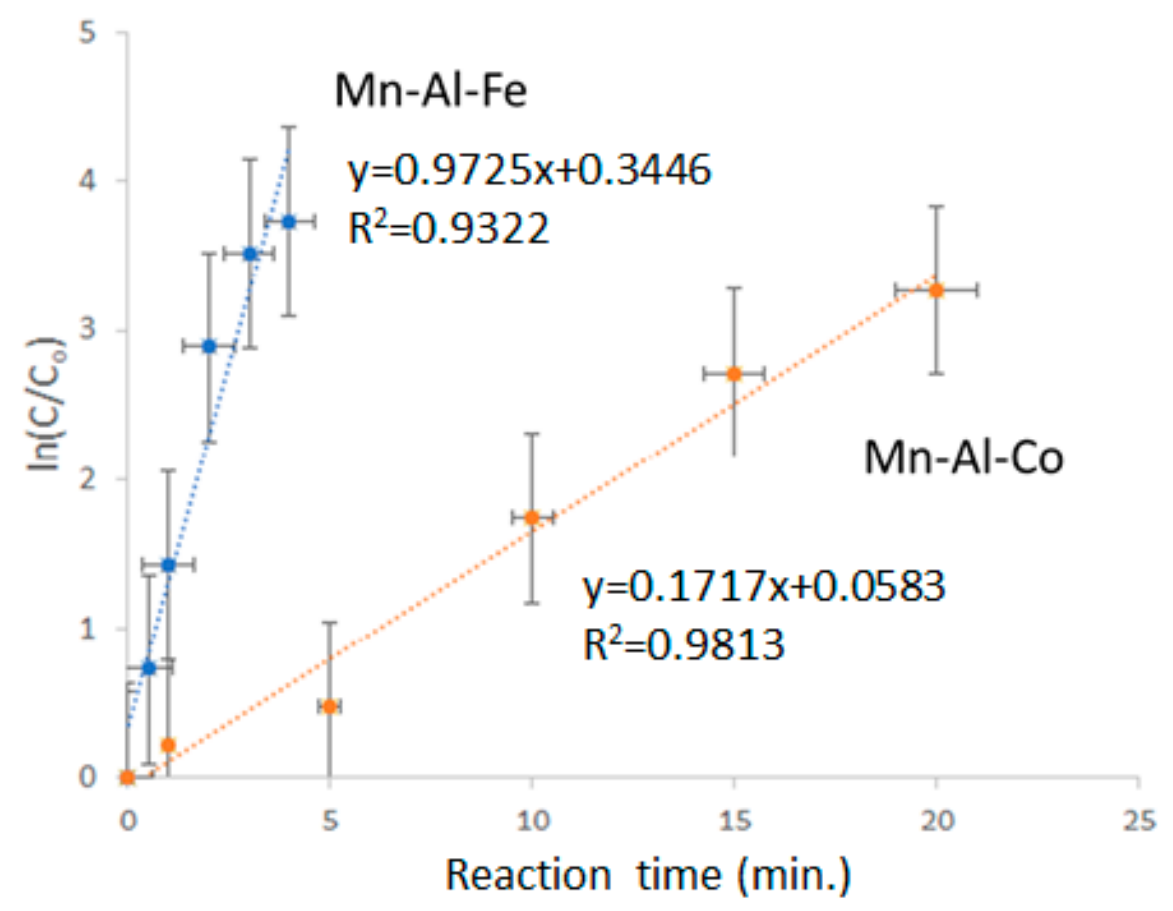

Figure 4. $\mathrm{Ln}\left(\mathrm{C} / \mathrm{C}_{\mathrm{o}}\right)$ versus reaction time of the MA Mn-Al-Fe and Mn-Al-Co alloys. 
The appearance of bubbles was detected inside the solution. This effect is associated with the formation of hydrogen gas. Resting upon this fact, the proposed mechanism of the dye degradation operates as a result of the release of: (a) $\mathrm{H}_{2}$ from the reduction in water, (b) the cleavage of $-\mathrm{N}=\mathrm{N}$ bonds and, (c), the formation of $-\mathrm{NH}_{2}$ groups. Under these conditions, the release of hydrogen gas is accompanied by the formation of insoluble metal hydroxides [19,37]. The mechanism for Mn-Al-Fe and $\mathrm{Mn}-\mathrm{Al}-\mathrm{Co}$, in acid conditions, are based on the reactions of these references. Here, we introduce Fe and Co reactions. The reactions involving Fe are:

$$
\begin{gathered}
\mathrm{Fe} \rightarrow \mathrm{Fe}^{3+}+3 \mathrm{e}^{-} \\
\mathrm{Fe}^{3+}+3(\mathrm{OH})^{-} \rightarrow \mathrm{Fe}(\mathrm{OH})_{3}
\end{gathered}
$$

The main difference with previous works in $\mathrm{Mn}-\mathrm{Al}$ alloys is the role of Fe. The mechanism for $\mathrm{Mn}-\mathrm{Al}-\mathrm{Co}$ is similar, taking into account the Co reactions $(\mathrm{pH}<7)$ in substitution of Fe reactions [38]

$$
\begin{gathered}
\mathrm{Co} \rightarrow \mathrm{Co}^{2+}+2 \mathrm{e}^{-} \\
\mathrm{Co}^{2+}+2(\mathrm{OH})^{-} \rightarrow \mathrm{Co}(\mathrm{OH})_{2}
\end{gathered}
$$

The aluminum oxide can act as an acid or a basic agent relying on the environment by the $\mathrm{Al}(\mathrm{OH})_{3}$ and $\left[\mathrm{Al}(\mathrm{OH})_{4}\right]^{-}$formation. The $\mathrm{pH}$ of the solution increases (from 6.3 to 10.8 or 11.2 in $\mathrm{Mn}-\mathrm{Al}-\mathrm{Fe} / \mathrm{Mn}-\mathrm{Al}-\mathrm{Co}$, respectively) due to $\mathrm{OH}^{-}$ion enrichment. The mechanism proposed by the $\mathrm{Mn}-\mathrm{Al}-\mathrm{Fe}$ and $\mathrm{Mn}-\mathrm{Al}-\mathrm{Co}$ reaction, in basic conditions, $(\mathrm{pH}>7)$, is given in references $[19,38]$. The reactions involving $\mathrm{Fe}$ and $\mathrm{Co}$ are the same.

To assess the product of the discoloration reaction by the Mn-Al-Fe (or Mn-Al-Co) powder, we observed the surface of the particles by scanning electron microscopy. The micrographs obtained are plotted in Figures 5 and 6 and unveil that some products of the reaction are spread (uniformly distributed) over the entire particle's surface. The same effect was found in other metallic compounds [39]. These crystalline precipitates are mainly composed of the element $\mathrm{Al}$ and oxygen. In addition, a high amount of corrosion holes was detected on the surface of the alloys, indicating that corrosion of the alloy particles during the degradation process of RB5 occurs by pitting [19]. It is well known that the corrosion of the Al-based alloy is dependent on the damage of the $\mathrm{Al}_{2} \mathrm{O}_{3}$-passive layer. In addition, it is believed that pitting corrosion is one of the main degradation mechanisms of RB5. This result is very expressive, the addition of an acid to the initially alkaline textile industrial wastewater unnecessary. Likewise, the cationic metals concentrations of $\mathrm{Mn}, \mathrm{Al}, \mathrm{Fe}$ and $\mathrm{Co}$ are obtained from absorption spectrometry: $2.12,<0.59,<0.16$ and $<0.20 \mathrm{mg} \mathrm{L}^{-1}$ (detection limit) for $\mathrm{Mn}, \mathrm{Al}, \mathrm{Fe}$ and $\mathrm{Co}$, respectively. The dissolution of $\mathrm{Al}(\mathrm{OH})_{3}$ results from the excess of $\mathrm{OH}^{-}$, and therefore more surface is exposed to water favoring the progression of the reactions. 

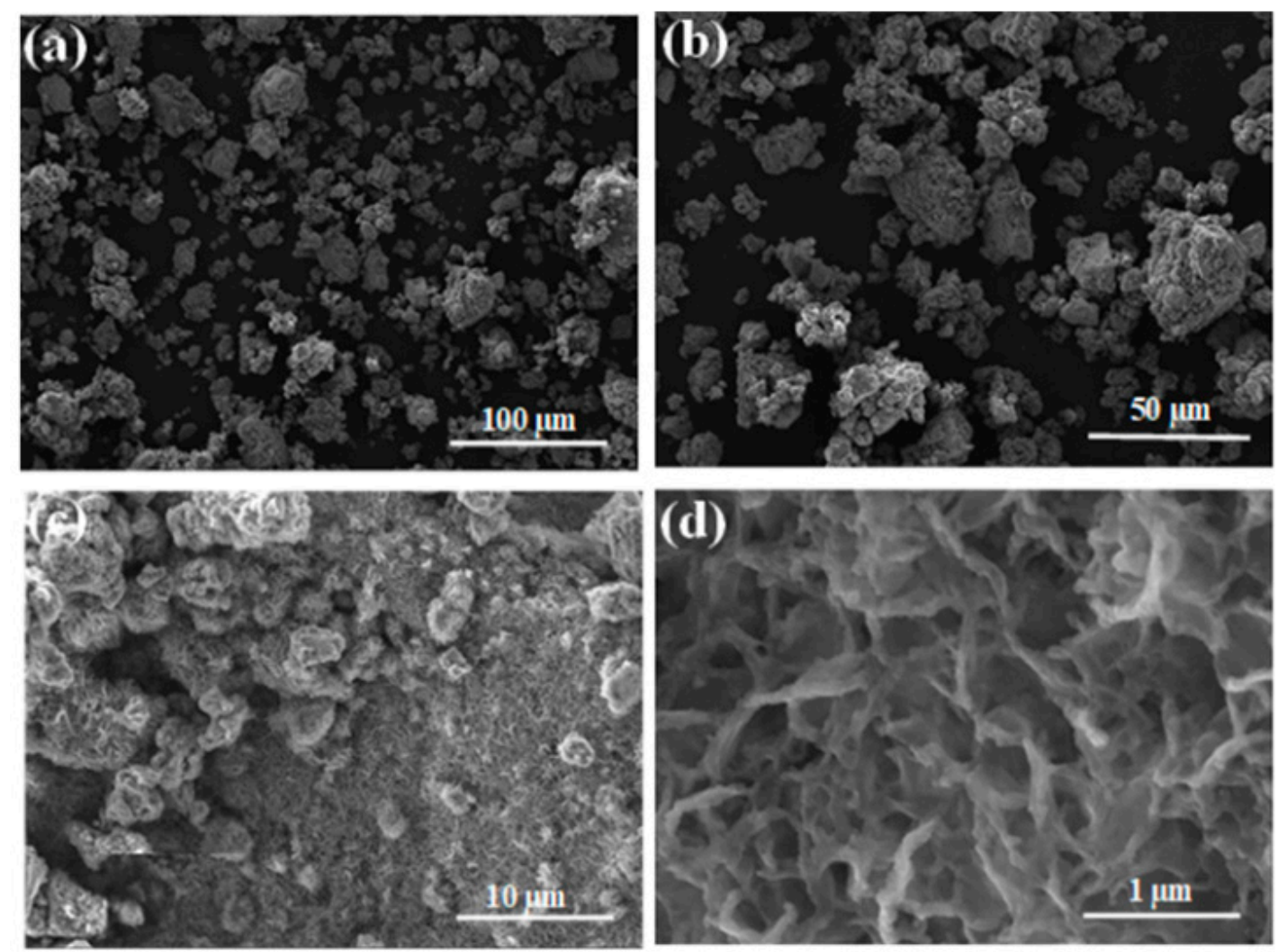

Figure 5. SEM micrographs of MA Mn-Al-Fe after RB5 degradation at different magnifications. Scale bars: (a) $100 \mu \mathrm{m}$, (b) $500 \mu \mathrm{m}$, (c) $10 \mu \mathrm{m}$ and (d) $1 \mu \mathrm{m}$.
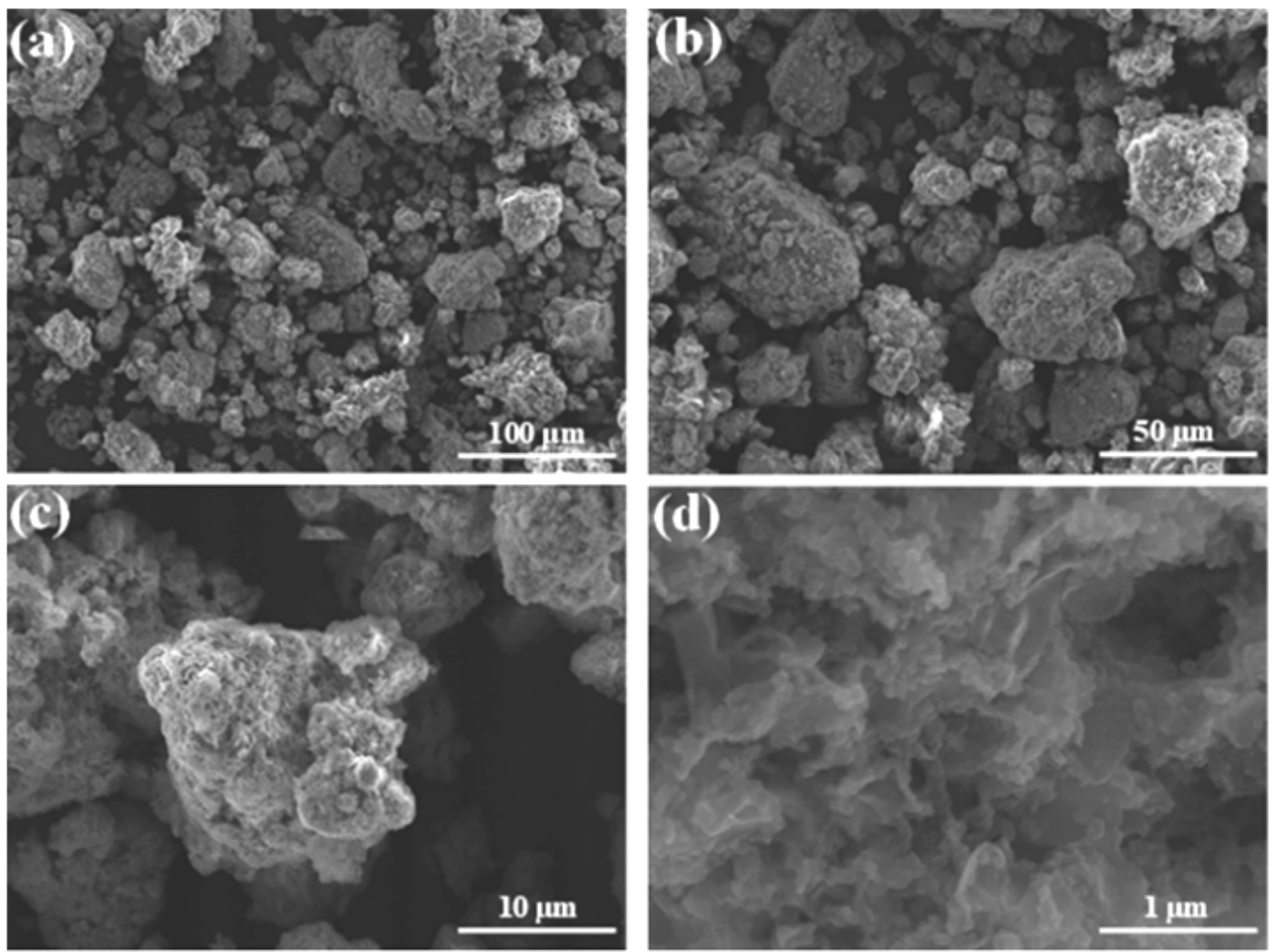

Figure 6. SEM micrographs of MA Mn-Al-Co after RB5 degradation at different magnifications. Scale bars: (a) $100 \mu \mathrm{m},(\mathbf{b}) 500 \mu \mathrm{m}$, (c) $10 \mu \mathrm{m}$ and (d) $1 \mu \mathrm{m}$. 
After the decoloring reaction, the size distributions of the Mn-Al-Fe and Mn-Al-Co alloys are illustrated in Figure 7a,c, respectively, showing mean sizes of the order of 20 and $17 \mu \mathrm{m}$. This difference in size is associated to the precipitates on the surface of the nanostructured powders. The corresponding EDS analyzes depicted in Figure $7 \mathrm{~b}, \mathrm{~d}$ indicate the approximately compositions of the elements, Mn 50.0/Al: 15.0/Fe: 8.0/O: 27.0 for the Mn-Al-Fe alloy, and Mn: 47.0/Al: 17.0/Co: 10.0/O: 26.0 for the Mn-Al-Co alloy. Finally, the microstructural study of Mn-Al-Fe and Mn-Al-Co powders before and after RB5 dye degradation $(\mathrm{pH}<7$ ) is performed by XRD. The results are shown (see Figure $8 \mathrm{a}, \mathrm{b})$. The diffraction patterns obtained before the degradation of the two $\mathrm{Mn}-\mathrm{Al}-\mathrm{Fe} / \mathrm{Mn}-\mathrm{Al}-\mathrm{Co}$ powders reveal the coexistence of a solid solution of $\mathrm{MnAlFe}_{2}$ (JCPD 00-054-0388) and MnAlCo 2 (JCPD 03-065-5185) phases, respectively, (B2, space group Fm3m) with traces of very small proportions of MnAl phase ( $\eta$ ) rich in Al and tetragonal face-centered (FCT) structure [40]. The average crystallite size of the solid solution B2 is of $60 \pm 3 \mathrm{~nm}$. This nanocrystalline structure may stand for another factor increasing the reactivity of these metal powders within the aqueous dyed solutions by increasing atoms in the boundary regions. As two phases are detected after MA, the samples are not chemically homogeneous. Nevertheless, the fast discoloration kinetics allow us to state that this chemical in-homogeneity is probably not determinant. The inspection of the X-ray diffraction patterns of both powdered alloys obtained after the discoloration reaction demonstrates the appearance of new phases identified as: $\mathrm{Al}(\mathrm{OH})_{3}$ (JCPD 00-003 -0915), $\mathrm{Fe}(\mathrm{OH})_{3}$ (JCPD 00-038-0032), and $\mathrm{Co}(\mathrm{OH})_{2}$ (JCPD 00-051-173) beside the $\mathrm{B} 2-\mathrm{MnAl}(\mathrm{Fe}, \mathrm{Co})_{2}$ and $\eta-\mathrm{MnAl}$ phases (Figure $\left.8 \mathrm{a}, \mathrm{b}\right)$. The products resemble micro-precipitates of $\mathrm{Al}(\mathrm{OH})_{3}, \mathrm{Fe}(\mathrm{OH})_{3}$ and $\mathrm{Co}(\mathrm{OH})_{2}$ hydroxides, covering the surface of the particles. These hydroxides are minor phases (>10 at.\%). It should be remarked that it is likely that in all phases, including hydroxides, all elements ( $\mathrm{Mn}, \mathrm{Al}, \mathrm{Fe}$ or $\mathrm{Co}$ ) are present: one with a high amount and the other two elements in solid solution. Likewise, EDS analysis gives information about the volume of the powder near the surface, not the overall volume of the powders.
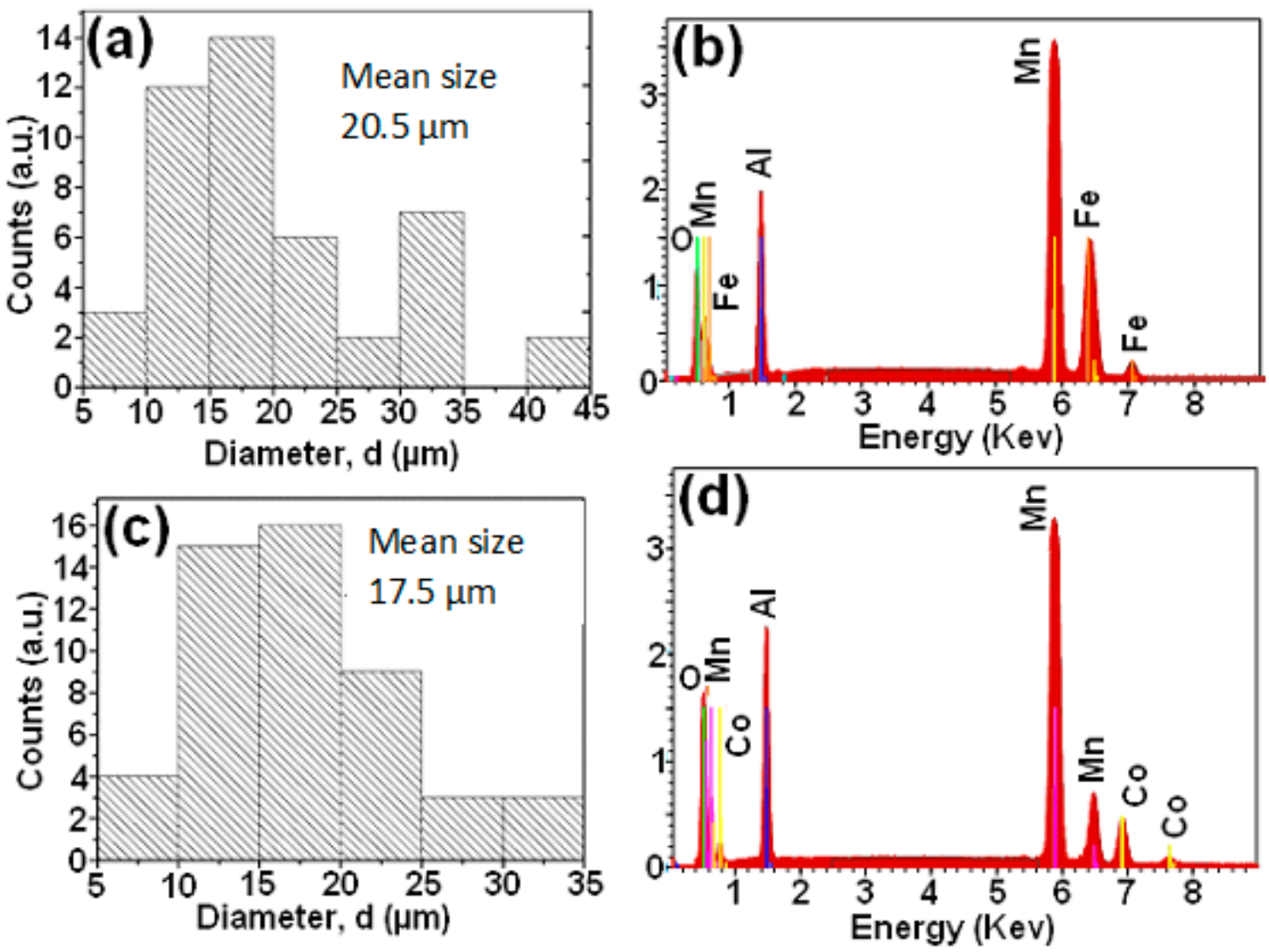

Figure 7. Distribution of particle sizes of MA powders after decoloring reaction: (a) Mn-Al-Fe, (b) Mn-Al-Co. EDS microanalysis: (c) Mn-Al-Fe and (d) Mn-Al-Co. 

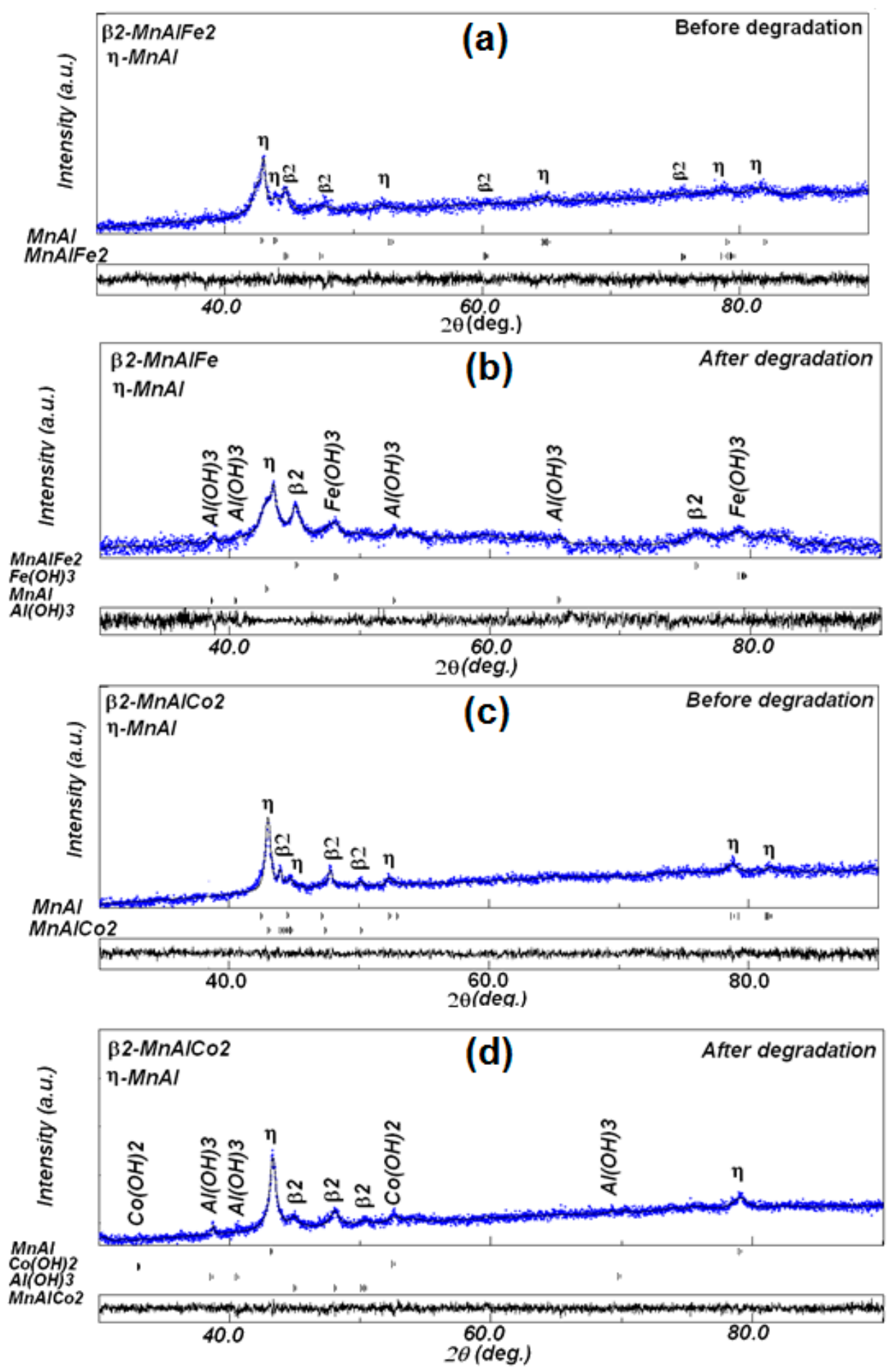

Figure 8. XRD diffraction patterns: (a,b) MA Mn-Al-Fe powder before and after degradation and (c,d) MA Mn-Al-Co powder before and after degradation.

It has been reported that MA can favor a higher specific surface area [22]. This parameter, determined by BET, provides best information about the active surface than the statistical analysis of powders' size distribution from SEM micrographs. The higher the specific surface, the higher the interaction between particles and the dye molecule. The specific surface area was $0.50 \pm 0.02 \mathrm{~m}^{2} \mathrm{~g}^{-1}$ for the Mn-Al-Fe alloy and $0.45 \pm 0.02 \mathrm{~m}^{2} \mathrm{~g}^{-1}$ for the Mn-Al-Co alloy. There is apparently a slight difference in the specific surface. Nevertheless, fast discoloration was found in the sample with Fe 
addition (the slopes of Figure 4 are 0.9725 and $0.1727 \mathrm{~s}^{-1}$ in alloys with Fe and Co, respectively). This high difference is due to the high surface area of the sample with $\mathrm{Fe}$, but can also be partially attributed, as discussed above, to the different chemical compositions of the alloys.

Thus, the results make these two alloys promising candidates for the fast degradation of different azo dyes. In Mn-Al MA powders, the specific surface values were found to range between 0.55 and $0.48 \mathrm{~m}^{2} \mathrm{~g}^{-1}$. Values between 0.50 and $0.55 \mathrm{~m}^{2} \mathrm{~g}^{-1}$ were found by other authors [41].

The FTIR spectra of RB5 before and after degradation were shown in Figure 9. The main peaks and bands identification are given in Table 1.

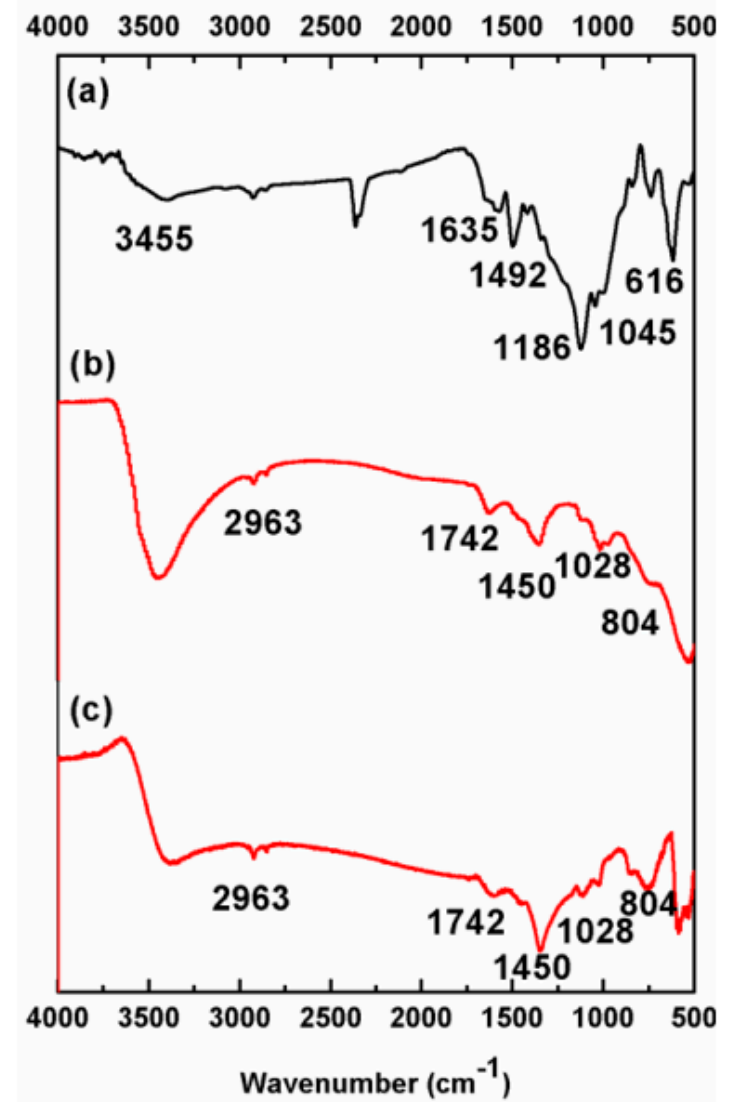

Figure 9. FTIR spectra: (a) RB5 powder before degradation selection. (b,c) Mn-Al-Fe and Mn-Al-Co powders after degradation, respectively.

Table 1. FTIR peaks/bands identification [42-46].

\begin{tabular}{cc}
\hline Peak/Band & Identification \\
\hline $3455 \mathrm{~cm}^{-1}$ & $\mathrm{O}-\mathrm{H}$ stretching vibration \\
$1742 \mathrm{~cm}^{-1}$ & $\mathrm{C}=\mathrm{C}$ stretching vibration \\
$1635 \mathrm{~cm}^{-1}$ & azo bond (-N=N-) \\
$1528 \mathrm{~cm}^{-1}$ & $\mathrm{~N}-\mathrm{H}$ stretching vibration \\
$1492 \mathrm{~cm}^{-1}$ & $\mathrm{C}=\mathrm{C}$ aromatic skeletal vibrations \\
$1260 \mathrm{~cm}^{-1}$ & $\mathrm{C}-\mathrm{N}$ stretching vibration \\
$1186 \mathrm{~cm}^{-1}$ & $\mathrm{C}-\mathrm{OH}$ stretching vibration \\
$1045 \mathrm{~cm}^{-1}$ & $\mathrm{C}-\mathrm{OH}$ stretching vibration \\
$1028 \mathrm{~cm}^{-1}$ & benzene mode coupling with stretching vibration of $-\mathrm{SO}_{3}$ \\
$804 \mathrm{~cm}^{-1}$ & $-\mathrm{CH} \mathrm{H}_{3}$ skeletal vibration \\
$616 \mathrm{~cm}^{-1}$ & sulfonic group \\
\hline
\end{tabular}

From FTIR spectra, it is clear that some characteristic RB5 peaks decrease during the reaction, while some new peaks appear. The decreasing peaks are the azo bond $\left(-\mathrm{N}=\mathrm{N}-\right.$, at $\left.1635 \mathrm{~cm}^{-1}\right)$ and 
the naphthalene ring $\left(C=C\right.$ aromatic skeletal vibration, at $\left.1400-1600 \mathrm{~cm}^{-1}\right)$. A minor peak remains in all FTIR spectra, the $2963 \mathrm{~cm}^{-1}$ peak, assigned to the skeletal vibration of the benzene ring. Some new peaks appear after degradation, located at 1742, 1528 and $1260 \mathrm{~cm}^{-1}$ (stretching vibration of $\mathrm{C}=\mathrm{C}, \mathrm{N}-\mathrm{H}$ and $\mathrm{C}-\mathrm{N}$ bonds, respectively). This demonstrates that the reductive cleavage of the $-\mathrm{N}=\mathrm{N}-$ bond $[19,44]$ favors the presence of amines. It should be remarked that amines are also water-pollutant. Mn-Al based alloys' application in industrial processes will be combined with an ulterior amine adsorption process. Thus, metallic nanostructured particles are candidates for the first step of a combined multi-step procedure.

In addition, these results are in good accordance with the previously stated UV-Vis (Figure 3b,c) regarding the cleavage of the azo bands [42,44-46]. The FTIR confirms that the results indicated that the azo bond and the naphthalene ring are broken by mechanical alloying of $\mathrm{Mn}-\mathrm{Al}-(\mathrm{Fe}, \mathrm{Co})$ and result in the formation of amino and alkyl compounds.

The HPLC chromatograms are shown in Figure 10. Before degradation, the major peak has a molecular weight of 991. Similar results were elaborated by Shilpa and coworkers [46], Patel and coworkers [47] and Ben Mbarek [19,20]. The RB5 chromatography should be compared with the HPLC chromatography and LC-MS mass spectrums of the solutions after degradation with the metallic alloys.
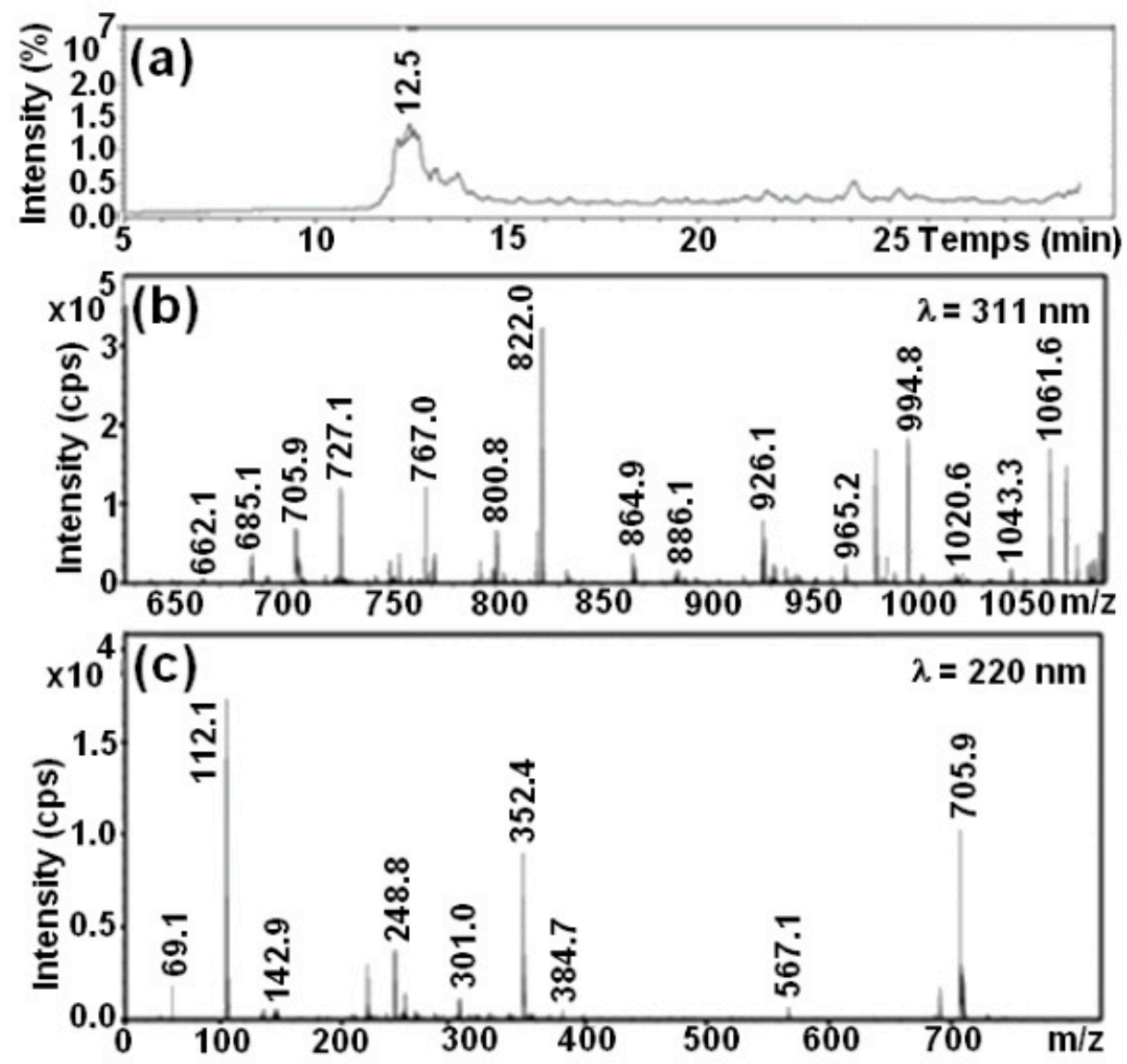

Figure 10. (a) HPLC profile of RB5 dye solution. Mass spectrums of peaks from $10.5 \mathrm{~min}$ at $(\mathbf{b}) \lambda=311$ $\mathrm{nm}$ and $(\mathrm{c}) \lambda=220 \mathrm{~nm}$.

Figure 11 displays the LC-MS analyses of the extract of the two solutions obtained following the degradation reactions carried out by the two ternary powders $\mathrm{Mn}-\mathrm{Al}-\mathrm{Fe}$ and $\mathrm{Mn}-\mathrm{Al}-\mathrm{Co}$. These analyses reveal several retention time peaks. In addition, analyses of the major peaks eluted between 10 and $15 \mathrm{~min}$ demonstrated the existence of two peaks at 349 and $280.1 \mathrm{~m} / \mathrm{z}$ in relation to the final amino molecules, related to 1-2-7-triamino-8-hydroxy,3-6-naphthalenedisulfonate and 1-sulfonic acid, 2-(4-aminobenzenesulfonyl) ethanol, as depicted in Figure 10a,b. All these results confirm the 
appearance of aromatic amino compounds emerging from the decomposition reaction of the large RB5 organic molecule. This is inferred through the appearance of signals at $248.9 \mathrm{~m} / \mathrm{z}$, related to the aromatic amines obtained after bond cleavage. The mechanism of discoloration of RB5 with these metal powders can only be identical to that identified for the case of the Mn-Al binary following the cleavage of the azo bonds [19].
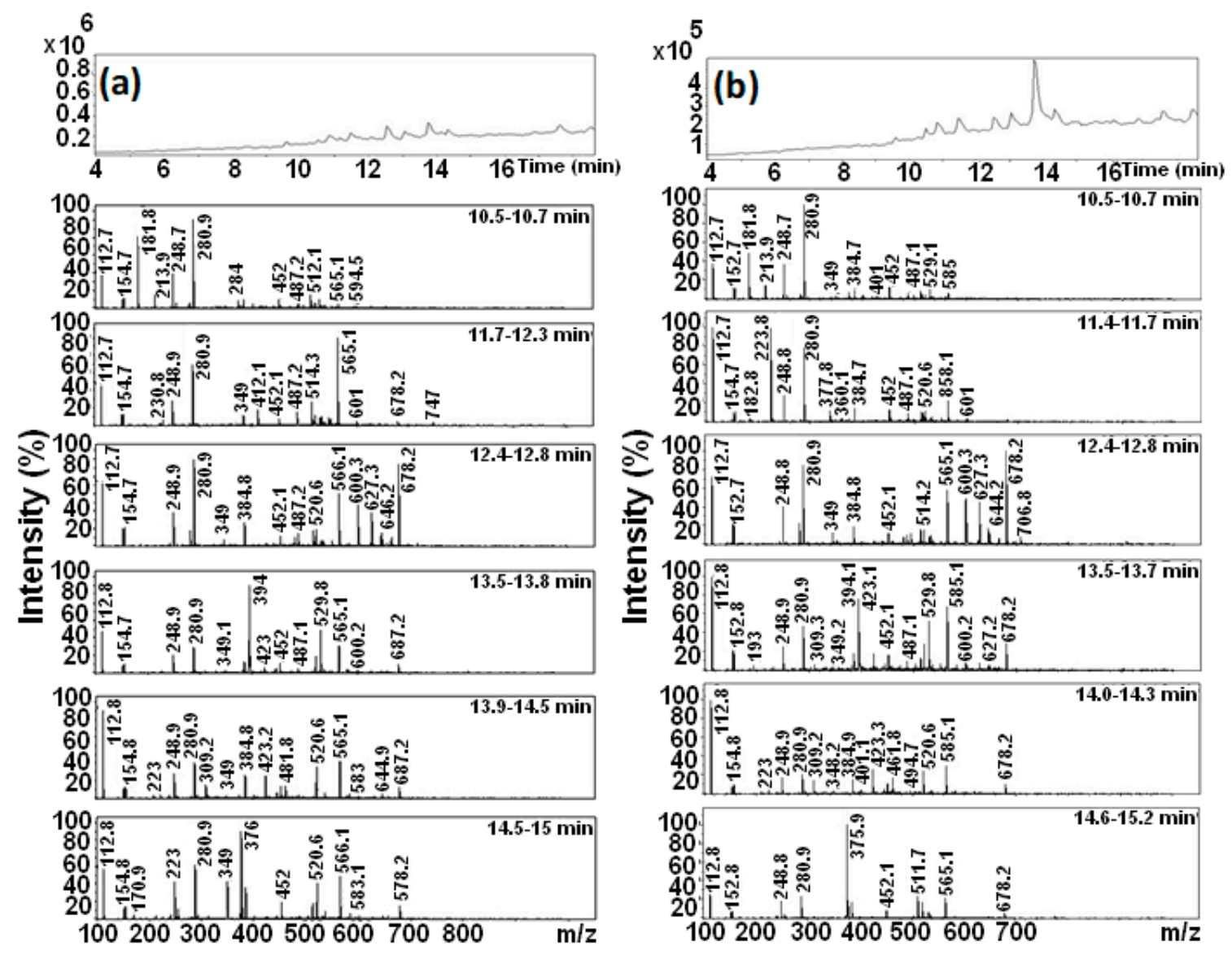

Figure 11. HPLC evolution profiles after degradation of the RB5 dye and mass spectrum of peaks from 10.5 to 15.2 min of the MA powders: (a) Mn-Al-Fe and (b) Mn-Al-Co.

\section{Conclusions}

In sum, Mn-Al-Fe and Mn-Al-Co powders were successfully manufactured by mechanical alloying. The efficiency and kinetics of the discoloration reaction of aqueous solutions of RB5 are systematically evaluated to determine the capacity of these two alloys in the bleaching reaction.

- The Mn-Al-Fe powder displays an excellent degradation efficiency and the kinetics of the reaction are proven to be faster than that of Mn-Al based alloys with 10 at.\% of Fe and Co. The high efficiency of the Mn-Al-Fe powder is associated with the configuration of valence electrons. This favors a higher concentration of reactive (hole) sites in the d-band for iron than that for cobalt (forming a localized adsorption bond with the adsorbate molecule), favoring a stronger adsorption capacity;

- For the ternary alloy with $\mathrm{Fe}$, the solution is fully discolored in $5 \mathrm{~min}$, whereas for the solution with $\mathrm{Co}$, the reaction time to full decolorization is $20 \mathrm{~min}$. The reductive cleavage of the $-\mathrm{N}=\mathrm{N}$ bond was demonstrated by FTIR spectra analysis;

- Furthermore, the zero-valent iron $\left(\mathrm{Fe}^{0}\right)$ and the zero valent cobalt $\left(\mathrm{Co}^{0}\right)$ become reaction actors to promote the production of hydrogen from water. Likewise, the decolorization of R5 solution is 
consistent with first-order kinetics. Hence, the high efficiency of Mn-Al based alloys recorded in decolorization treatments of dyed wastewaters, already emphasized in previous works, can be modified and increased by minor alloying with other transition metals.

Thus, these promising materials have interesting characteristics to be applied, probably in a multi-step procedure in the wastewater treatment in the textile industry.

Author Contributions: Methodology, L.E., J.S.; formal analysis, W.B.M.; investigation, W.B.M.; resources, E.P., J.-J.S.; data curation, L.E., M.K.; writing—original draft preparation, W.B.M., J.-J.S.; supervision, L.E.; funding acquisition, E.P., J.-J.S. All authors have read and agreed to the published version of the manuscript.

Funding: Work funded by Spanish MINECO Grant No. FIS2017-82625-P, Catalan GenCat Grant No. 2017SGR0042 and University of Girona UNIGE-2-2019 project is also acknowledged.

Acknowledgments: The authors acknowledge the technical facilities of the STR support to research units of the University of Girona.

Conflicts of Interest: The authors declare no conflict of interest.

\section{References}

1. Amin, N.K. Removal of direct blue-106 dye from aqueous solution using new activated carbons developed from pomegranate peel: Adsorption equilibrium and kinetics. J. Hazard. Mater. 2009, 165, 52-62. [CrossRef] [PubMed]

2. Fu, W.; Yang, H.; Chang, L.; Hari-Bala; Li, M.; Zou, G. Anatase TiO2 nanolayer coating on strontium ferrite nanoparticles for magnetic photocatalyst. Colloids Surf. A Physicochem. Eng. Asp. 2006, 289, 47-52. [CrossRef]

3. Daneshvar, N.; Aber, S.; Khani, A.; Khataee, A.R. Study of imidaclopride removal from aqueous solution by adsorption onto granular activated carbon using an on-line spectrophotometric analysis system. J. Hazard. Mater. 2007, 144, 47-51. [CrossRef] [PubMed]

4. Walker, S.; Narbaitz, R.M. Hollow fiber ultrafiltration of Ottawa River water: Floatation versus sedimentation pre-treatment. Chem. Eng. J. 2016, 288, 228-237. [CrossRef]

5. Okolo, B.I.; Nnaji, P.C.; Onukwuli, O.D. Nephelometric approach to study coagulation-flocculation of brewery effluent medium using Detarium microcarpum seed powder by response surface methodology. J. Environ. Chem. Eng. 2016, 4, 992-1001. [CrossRef]

6. Gupta, M.K.; Mittal, A.K. Integrated biological and advanced oxidation based treatment of hexamine bearing wastewater: Effect of cow-dung as a co-substrate. J. Hazard. Mater. 2016, 308, 394-401. [CrossRef]

7. Khani, A.; Sohrabi, M.R.; Khosravi, M.; Davallo, M. Enhancing purification of an azo dye solution in nanosized zero-valent iron-ZnO photocatalyst system using subsequent semibatch packed-bed reactor. Turkish J. Eng. Environ. Sci. 2013, 37, 91-99. [CrossRef]

8. Khani, A.; Pezeshki, B. Easy simultaneous synthesis-immobilization of nanosized $\mathrm{CuO}-\mathrm{ZnO}$ on perlite as a photocatalyst for degradation of acid orange 7 from aqueous solution in the presence of visible light. Desalin. Water Treat. 2016, 57, 7047-7053. [CrossRef]

9. Xie, T.; Yang, J.; Peng, Y.; Wang, J.; Liu, S.; Xu, L.; Liu, C. $\beta$-Bi2O3/SrFe12O19 magnetic photocatalyst: Facile synthesis and its photocatalytic activity. Mater. Technol. 2019, 34, 843-850. [CrossRef]

10. Kanel, S.R.; Manning, B.; Charlet, L.; Choi, H. Removal of arsenic(III) from groundwater by nanoscale zero-valent iron. Environ. Sci. Technol. 2005, 39, 1291-1298. [CrossRef]

11. Schrick, B.; Blough, J.L.; Jones, A.D.; Mallouk, T.E. Hydrodechlorination of trichloroethylene to hydrocarbons using bimetallic nickel-iron nanoparticles. Chem. Mater. 2002, 14, 5140-5147. [CrossRef]

12. Chang, J.H.; Cheng, S.F. The remediation performance of a specific electrokinetics integrated with zero-valent metals for perchloroethylene contaminated soils. J. Hazard. Mater. 2006, 131, 153-162. [CrossRef] [PubMed]

13. Xiong, Z.; Zhao, D.; Pan, G. Rapid and complete destruction of perchlorate in water and ion-exchange brine using stabilized zero-valent iron nanoparticles. Water Res. 2007, 41, 3497-3505. [CrossRef] [PubMed]

14. Hu, J.; Lo, I.M.C.; Chen, G. Fast removal and recovery of $\mathrm{Cr}(\mathrm{VI})$ using surface-modified jacobsite (MnFe2O4) nanoparticles. Langmuir 2005, 21, 11173-11179. [CrossRef] [PubMed]

15. ChangQin, Z.; ZhengWang, Z.; HaiFeng, Z.; ZhuangQi, H. Article Rapid reductive degradation of azo dyes by a unique structure of amorphous alloys. Chin. Sci. Bull. 2011, 56, 3988-3992. [CrossRef] 
16. Zhang, Z.; Wang, Y.; Qi, Z.; Zhang, W.; Qin, J.; Frenzel, J. Generalized fabrication of nanoporous metals (Au, $\mathrm{Pd}, \mathrm{Pt}, \mathrm{Ag}$, and Cu) through chemical dealloying. J. Phys. Chem. C 2009, 113, 12629-12636. [CrossRef]

17. Pugh, D.V.; Dursun, A.; Corcoran, S.G. Electrochemical and morphological characterization of $\mathrm{Pt}-\mathrm{Cu}$ dealloying. J. Electrochem. Soc. 2005, 152, B455-B459. [CrossRef]

18. Mangipudi, K.R.; Epler, E.; Volkert, C.A. Morphological similarity and structure-dependent scaling laws of nanoporous gold from different synthesis methods. Acta Mater. 2017, 140, 337-343. [CrossRef]

19. Ben Mbarek, W.; Azabou, M.; Pineda, E.; Fiol, N.; Escoda, L.; Suñol, J.J.; Khitouni, M. Rapid degradation of azo-dye using Mn-Al powders produced by ball-milling. RSC Adv. 2017, 7, 12620-12628. [CrossRef]

20. Ben Mbarek, W.; Pineda, E.; Escoda, L.; Suñol, J.J.; Khitouni, M. High efficiency decolorization of azo dye Reactive Black 5 by Ca-Al particles. J. Environ. Chem. Eng. 2017, 5, 6107-6113. [CrossRef]

21. AboliGhasemabadi, M.; Mbarek, W.B.; Casabella, O.; Roca-Bisbe, H.; Pineda, E.; Escoda, L.; Suñol, J.J. Application of mechanically alloyed MnAl particles to de-colorization of azo dyes. J. Alloys Compd. 2018, 741, 240-245. [CrossRef]

22. AboliGhasemabadi, M.; Ben Mbarek, W.; Cerrillo-Gil, A.; Roca-Bisbe, H.; Casabella, O.; Blánquez, P.; Pineda, E.; Escoda, L.; Suñol, J.J. Azo-dye degradation by Mn-Al powders. J. Environ. Manag. 2020, 258, 110012. [CrossRef] [PubMed]

23. Petcharoen, K.; Sirivat, A. Synthesis and characterization of magnetite nanoparticles via the chemical co-precipitation method. Mater. Sci. Eng. B Solid State Mater. Adv. Technol. 2012, 177, 421-427. [CrossRef]

24. Devatha, C.P.; Thalla, A.K.; Katte, S.Y. Green synthesis of iron nanoparticles using different leaf extracts for treatment of domestic waste water. J. Clean. Prod. 2016, 139, 1425-1435. [CrossRef]

25. Wu, S.; Pan, Y.; Lu, J.; Wang, N.; Dai, W.; Lu, T. Effect of the addition of Mg, Ti, Ni on the decoloration performance of AlCrFeMn high entropy alloy. J. Mater. Sci. Technol. 2019, 35, 1629-1635. [CrossRef]

26. Feng, Y.P.; Gaztelumendi, N.; Fornell, J.; Zhang, H.Y.; Solsona, P.; Baró, M.D.; Suriñach, S.; Ibáñez, E.; Barrios, L.; Pellicer, E.; et al. Mechanical properties, corrosion performance and cell viability studies on newly developed porous Fe-Mn-Si-Pd alloys. J. Alloys Compd. 2017, 724, 1046-1056. [CrossRef]

27. Hermawan, H.; Alamdari, H.; Mantovani, D.; Dubé, D. Iron-manganese: New class of metallic degradable biomaterials prepared by powder metallurgy. Powder Metall. 2008, 51, 38-45. [CrossRef]

28. Cao, J.; Wei, L.; Huang, Q.; Wang, L.; Han, S. Reducing degradation of azo dye by zero-valent iron in aqueous solution. Chemosphere 1999, 38, 565-571. [CrossRef]

29. Feng, W.; Nansheng, D.; Helin, H. Degradation mechanism of azo dye C. I. reactive red 2 by iron powder reduction and photooxidation in aqueous solutions. Chemosphere 2000, 41, 1233-1238. [CrossRef]

30. Stylidi, M.; Kondarides, D.I.; Verykios, X.E. Pathways of solar light-induced photocatalytic degradation of azo dyes in aqueous TiO2 suspensions. Appl. Catal. B Environ. 2003, 40, 271-286. [CrossRef]

31. Zhang, C.; Zhang, H.; Lv, M.; Hu, Z. Decolorization of azo dye solution by Fe-Mo-Si-B amorphous alloy. J. Non. Cryst. Solids 2010, 356, 1703-1706. [CrossRef]

32. Zhang, C.; Zhu, Z.; Zhang, H. Effects of the addition of $\mathrm{Co}, \mathrm{Ni}$ or $\mathrm{Cr}$ on the decolorization properties of Fe-Si-B amorphous alloys. J. Phys. Chem. Solids 2017, 110, 152-160. [CrossRef]

33. Wang, J.Q.; Liu, Y.H.; Chen, M.W.; Xie, G.Q.; Louzguine-Luzgin, D.V.; Inoue, A.; Perepezko, J.H. Rapid degradation of Azo dye by Fe-based metallic glass powder. Adv. Funct. Mater. 2012, 22, 2567-2570. [CrossRef]

34. Nam, S.; Tratnyek, P.G. Reduction of azo dyes with zero-valent iron. Water Res. 2000, 34, 1837-1845. [CrossRef]

35. Zhang, C.; Zhu, Z.; Zhang, H.; Hu, Z. Rapid decolorization of Acid Orange II aqueous solution by amorphous zero-valent iron. J. Environ. Sci. 2012, 24, 1021-1026. [CrossRef]

36. Zhang, C.; Zhu, Z.; Zhang, H.; Sun, Q.; Liu, K. Effects of cobalt content on the decolorization properties of Fe-Si-B amorphous alloys. Results Phys. 2018, 10, 1-4. [CrossRef]

37. Mook, W.T.; Aroua, M.K.; Szlachta, M.; Lee, C.S. Optimisation of Reactive Black 5 dye removal by electrocoagulation process using response surface methodology. Water Sci. Tech. 2017, 75, 852. [CrossRef]

38. Garcia, E.M.; Santos, J.S.; Pereira, E.C.; Freitas, M.B.J.G. Electrodeposition of cobalt from spent Li-ion battery cathodes by the electrochemistry quartz crystal microbalance technique. J. Power Sources 2008, 185, 549-553. [CrossRef] 
39. Zhang, L.; Gao, X.; Zhang, Z.; Zhang, M.; Cheng, Y.; Su, J. A doping lattice of aluminum and copper with accelerated electron transfer process and enhanced reductive degradation performance. Sci. Rep. 2016, 6, 31797. [CrossRef]

40. Paduani, C.; Schaf, J.; Persiano, A.I.C.; Ardisson, J.D.; Takeuchi, A.Y.; Riegel, I.C. Strong dependence of ferrimagnetic properties on Co concentration in the Mn1-xAl1-yCox+y system. Intermetallics 2010, 18, 1659-1662. [CrossRef]

41. Stylidi, M.; Kondarides, D.I.; Verykios, X.E. Visible light-induced photocatalytic degradation of Acid Orange 7 in aqueous TiO2 suspensions. Appl. Catal. B Environ. 2004, 47, 189-201. [CrossRef]

42. Méndez-Martínez, A.J.; Dávila-Jiménez, M.M.; Ornelas-Dávila, O.; Elizalde-González, M.P.; Arroyo-Abad, U.; Sirés, I.; Brillas, E. Electrochemical reduction and oxidation pathways for Reactive Black 5 dye using nickel electrodes in divided and undivided cells. Electrochim. Acta 2012, 59, 140-149. [CrossRef]

43. Almeida, E.J.R.; Corso, C.R. Comparative study of toxicity of azo dye Procion Red MX-5B following biosorption and biodegradation treatments with the fungi Aspergillus niger and Aspergillus terreus. Chemosphere 2014, 112, 317-322. [CrossRef] [PubMed]

44. Elías, V.R.; Sabre, E.V.; Winkler, E.L.; Satuf, M.L.; Rodriguez-Castellón, E.; Casuscelli, S.G.; Eimer, G.A. Chromium and titanium/chromium-containing MCM-41 mesoporous silicates as promising catalysts for the photobleaching of azo dyes in aqueous suspensions. A multitechnique investigation. Microporous Mesoporous Mater. 2012, 163, 85-95. [CrossRef]

45. Agrawal, S.; Tipre, D.; Patel, B.; Dave, S. Optimization of triazo Acid Black 210 dye degradation by Providencia sp. SRS82 and elucidation of degradation pathway. Process Biochem. 2014, 49, 110-119. [CrossRef]

46. Shilpa, S.; Shikha, R. Biodegradation of Dye Reactive Black-5 by a Novel Bacterial Endophyte. Int. Res. J. Environ. Sci. 2015, 4, 44-53. [CrossRef]

47. Patel, R.; Suresh, S. Decolourization of azo dyes using magnesium-palladium system. J. Hazard. Mater. 2006, 137, 1729-1741. [CrossRef]

Publisher's Note: MDPI stays neutral with regard to jurisdictional claims in published maps and institutional affiliations.

(C) 2020 by the authors. Licensee MDPI, Basel, Switzerland. This article is an open access article distributed under the terms and conditions of the Creative Commons Attribution (CC BY) license (http://creativecommons.org/licenses/by/4.0/). 